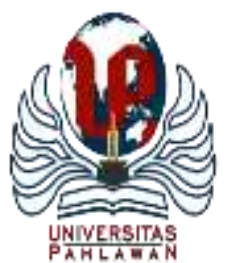

Edukatif : Jurnal Ilmu Pendidikan Volume 3 Nomor 6 Tahun 2021 Halm 4763 - 4770

EDUKATIF: JURNAL ILMU PENDIDIKAN

Research \& Learning in Education

https:/ledukatif.org/index.php/edukatif/index

\title{
Pelaksanaan Supervisi Akademik dan Kemampuan Manajemen Kelas dalam Pelaksanaan Tugas Guru MIN Kota Padang
}

\author{
Azvi Rahmi \\ STAIYastis Padang, Indonesia \\ E-mail : Azviyarmi53@gmail.com
}

\begin{abstract}
Abstrak
Pelaksanaan tugas guru dianggap sebagai salah satu faktor penting dalam menentukan kualitas pendidikan. Dari hasil studi pendahuluan ditemukan bahwa pelaksanaan tugas guru di MIN Kota Padang tidak berjalan sebagaimana mestinya. Tujuan penelitian ini adalah 1) pelaksanaan supervisi akademik terhadap pelaksanaan tugas guru min Kota Padang 2) kemampuan manajemen kelas terhadap pelaksanaan tugas min kota Padang. Penelitian ini dilaksanakan dengan menggunakan teknik metoda kuantitatif dengan pendekatan deskriptif. Populasi penelitian adalah 66 orang guru. Sampe 66 orang yang terpilih melalui teknik random sampling. Penelitian analisis model skala Likert yang telah diuji validitas dan realibilitasnya. Data ini dianalisis secara statistik menggunakan teknik deskriptif. Hasil analisis data menunjukan bahwa supervisi akademik memberikan dampak terhadap pelaksanaan tugas guru secara deskriptif bahwa supervisi akademik termasuk kategori cukup. Kemampuan manajemen kelas secara langsung berdampak terhadap pelakasnaan tugas guru secara deskriptif bahwa kemampuan manajemen kelas termasuk kategori cukup dan supervisi akademik melalui kemampuan manajemen kelas berkontribusi dalam pelaksanaan tugas guru dengan kategori cukup.
\end{abstract}

Kata Kunci: Pelaksanaan supervisi, Manajemen kelas dan Pelaksanaan tugas guru

\begin{abstract}
The implementation of teacher duties is considered as one of the important factors in determining the quality of education. From the results of the preliminary study, it was found that the implementation of teacher duties at MIN Padang City did not run as it should. Therefore, this study was designed to investigate the contribution of academic supervision and classroom management abilities to the implementation of teacher assignments. The objectives of this study are 1) the implementation of academic supervision on the implementation of the duties of teachers in Padang City 2) the ability of class management to carry out the tasks of the Padang city min teachers. This research was carried out using quantitative methods with a descriptive approach. The research population is 66 teachers. A sample of 66 people were selected through random sampling technique. Research analysis of the Likert scale model that has been tested for validity and reliability. This data was analyzed statistically using descriptive techniques. The results of data analysis show that academic supervision has an impact on the implementation of teacher duties descriptively that academic supervision is included in the sufficient category. Class management ability directly affects the implementation of teacher assignments descriptively that class management abilities are included in the sufficient category and academic supervision through class management abilities contributes to the implementation of teacher assignments in the sufficient category.
\end{abstract}

Keywords: Implementation of Supervision, Class Management and Implementation of Teacher Duties

Copyright (c) 2021 Azvi Rahmi

$\triangle$ Corresponding author

Email : Azviyarmi53@gmail.com

DOI : https://doi.org/10.31004/edukatif.v3i6.1488

ISSN 2656-8063 (Media Cetak)

ISSN 2656-8071 (Media Online)

Edukatif : Jurnal Ilmu Pendidikan Vol 3 No 6 Tahun 2021 p-ISSN 2656-8063 e-ISSN 2656-8071 
4764 Pelaksanaan Supervisi Akademik dan Kemampuan Manajemen Kelas dalam Pelaksanaan Tugas Guru MIN Kota Padang - Azvi Rahmi

DOI: https://doi.org/10.31004/edukatif.v3i6.1488

\section{PENDAHULUAN}

Proses pembelajaran di suatu lembaga pendidikan (sekolah) bertujuan untuk membantu siswa yang memiliki kepribadian, kecerdasan dan keterampilan, serta bertaqwa kepada Tuhan yang Maha Esa sesuai dengan tujuan pendidikan nasional. Sekolah sebagai pendidikan formal bertujuan membentuk manusia yang berkepribadian, dalam mengembangkan intelektual peserta didik dalam rangka mencerdaskan kehidupan bangsa. Menurut UU No.20 tahun 2003 tentang Sistem Pendidikan Nasional bahwa pendidikan adalah usaha sadar dan terencana, untuk mewujudkan suasana belajar dan proses pembelajaran agar peserta didik secara aktif mengembangkan potensi dirinya, untuk memiliki kekuatan spiritual keagamaan, pengendalian diri, kepribadian, kecerdasan, akhlak mulia, serta ketrampilan yang diperlukan oleh dirinya sendiri, masyarakat, Bangsa dan Negara (Perpres, 2005)

Pendidik merupakan tenaga profesional yang bertugas merencanakan, melaksanakan proses pembelajaran dan menilai hasil pembelajaran, melakukan bimbingan dan pelatihan, serta melakukan penelitian dan pengabdian kepada masyarakat, terutama bagi pendidik di perguruan tinggi. Untuk dapat melaksanakan tugas dan tanggung jawab diatas, seorang guru dituntut memiliki beberapa kemampuan dan keterampilan tertentu. Kemampuan dan ketrampilan tersebut sebagai bagian dari kompetensi profesionalisme guru. Kompetensi merupakan suatu kemampuan yang mutlak dimiliki oleh guru agar tugasnya sebagai pendidik dapat terlaksana dengan baik. Kompetensi guru terdiri dari (1) kompetensi kepribadian, (2) kompetensi profesional, (3) kompetensi pedagogik, (4) kompetensi sosial. Masalah-masalah dalam penglolaan kelas biasanya berupa tingkah laku mahasiswa yang dapat mempengaruhi efektivitas pembelajaran, ini merupakan tanggung jawab dosen di dalam kelas, bagaimana proses pembelajaran dapat berjalan dengan baik. ((Erpidawati \& Susanti, 2019), (Baharuddin, 2010), (Misro, 2021).

Sebagai lembaga pendidikan formal MIN memiliki tujuan untuk menyiapkan siswa yang beriman dan bertaqwa kepada Tuhan Yang Maha Esa, berbudi pekerti luhur, memiliki pengetahuan dan keterampilan. Oleh sebab itu, setiap personil sekolah perlu berinteraksi efektif dalam suatu sistem pendidikan guna mencapai tujuan yang telah ditetapkan. Para pelaksana pendidikan perlu berusaha secara terus menerus untuk meningkatkan mutu pendidikan. Program pendidikan yang dirancang dengan konsep yang baik dan teliti tidak akan banyak membawa hasil bagi peningkatan mutu pendidikan kalau tidak diiringi dengan pelaksanaan tugas dengan penuh dedikasi dan loyalitas guru yang tinggi. Jadi perencanaan pendidikan yang baik perlu diiringi dengan pelaksanaan yang baik. Dengan meningkatnya mutu dan kemampuan guru, guru agar dapat melaksanakan tugas dan tanggung jawabnya dengan lebih baik dan akan berdampak pada pencapaian tujuan pendidikan

Dengan menyadari pentingnya peranan guru dalam meningkatkan mutu pendidikan, maka pemerintah dalam hal ini Departemen Pendidikan Nasional (Depdiknas), sejak lama telah melakukan berbagai upaya untuk meningkatkan kemampuan teknis guru dalam melaksanakan pembelajaran melalui penataran-penataran, seminar, dan loka karya. Di samping itu pemerintah juga memberikan kemudahan-kemudahan bagi guru-guru yang akan melanjutkan pendidikan ketingkat yang lebih tinggi. Salah satu aspek yang menarik untuk dikaji dari sosok seorang guru adalah aspek kinerja (Putri \& Imaniyati, 2017) (Jumali, 2014), (Arfani \& Sugiyono, 2014), (Ninlawan, 2015), (Suhardan, 2012).

Seiring dengan itu pemerintah juga berupaya meningkatkan kesejahteraan guru antara lain dengan memberikan kemudahan-kemudahan pengurusan kenaikan pangkat, memperpanjang usia pensiun (dari 56 menjadi 60 tahun), memberikan tunjangan jabatan/struktural, memberikan tunjangan sertifikasi dan memberikan penghargaan dalam bentuk setia lencana pendidikan kepada guru yang mempunyai dedikasi tinggi dalam melaksanakan tugas. Usaha-usaha tersebut kelihatannya masih belum memberikan hasil yang mengembirakan. Di kota Padang mutu pendidikan diberbagai jenjang pendidikan masih merosot, termasuk pada jenjang sekolah dasar sampai sekolah menengah atas. 
Pelaksanaan tugas guru tercermin melalui tugas dan tanggung jawab guru dalam memberikan dan mentransformasikan berbagai pengetahuan dan keterampilan kepada peserta didik. Pelaksanakan tugas guru tersebut perlu mendapat perhatian dan dukungan dari berbagai pihak, agar dapat dilaksanakan guru sehingga siswa dapat belajar secara maksimal. Pada dasarnya terdapat seperangkat tugas yang harus dilaksanakan oleh guru berhubungan dengan profesinya menurut peraturan pemerintah nomor 74 tahun 2008 tentang guru pasal 52 ayat (1) mencakup kegiatan pokok guru yaitu "(1) merencanakan Pembelajaran, (2) melaksanakan pembelajaran, (3) menilai hasil pembelajaran, (4) membimbing dan melatih peserta didik, (5) melaksanakan tugas tambahan yang melekat pada pelaksanaan tugas pokok".

Berdasarkan peraturan pemerintah No 74 di atas guru dituntut melaksanakan kegiatan pokok semaksimal mungkin agar mutu pendidikan meningkat, namun berdasarkan hasil survei awal penulis di lapangan pada bulan November 2011 terlihat banyak guru yang masih melalaikan pelaksanaan tugasnya. Hal ini terlihat dari fenomena berikut ini: 1) sebagian guru tidak membuat rencana pelaksanaan pembelajaran (RPP) dalam proses pembelajaran, 2) Dalam melaksanakan pembelajaran guru masih memakai metode ceramah yang membuat anak bosan karena monoton, sehingga proses pembelajaran tidak efektif. 3) sebagian guru yang belum menggunakan evaluasi proses dalam pembelajaran, 4) tugas siswa terkadang tidak diperiksa guru sehingga banyak buku tugas siswa menumpuk di meja ruang majelis guru 5) masih ditemukan yang mengundur waktu masuk kelas, walaupun bel sebagai tanda masuk sudah berbunyi, sebagian guru masih di ruangan majelis guru sehingga jumlah jam tatap muka berkurang, 6) masih ditemukan guru meniggalkan catatan kepada siswa tanpa tatap muka, sehingga siswa tidak terbimbing terarahkan, dan kurang perhatian kepada siswanya.

Keberhasilan guru dalam melaksanakan tugas atau kewajiban untuk tercapainya fungsi dan tujuan pendidikan ditentukan oleh guru itu sendiri. Guru harus mampu melaksanakan peranannya secara profesional dalam menjawab tantangan masalah yang dihadapi dalam tugasnya. Oleh sebab itu perlunya suatu upaya untuk meningkatkan guru agar dapat melaksanakan tugasnya dengan optimal. Saat ini pelaskanaan tugas guru sangatlah berat, guru harus memakai sistim pelajaran dari dan luring, analisis keterbaruan di dalam penelitian ini tentunya guru harus merancang dan mengelola kelas secara efektif baik yang dilakukan secara daring maupun luring, sistim manajemen dan efisiensi waktu. Maka tujuan penelitian ini adalah mengambarkan pelaksanaan supervisi akademik dan pengelolaan manajemen kelas dalam pelaskanaan tugas guru.

\section{METODOLOGI PENELITIAN}

Jenis penelitian yang digunakan adalah penelitian deskriptif. Penelitian ini bertujuan untuk melihat seberapa jauh variabel mempengaruhi variabel terikat. Penelitian ini menjelaskan dan melihat bagaimana pelaskanaan supervisi akademik dalam pelaksanaan tugas guru dan seberapa bagaimana pelaskanaan supervisi akademik melalui pengetahuan manajemen dalam pelaksanaan tugas guru Min Kota Padang. Populasi di dalam penelitian ini guru Ibtidaiyah Kota Padang yang berjumlah sebanyak 66 orang. Instrumen pengumpulan data menggunakan alat pengumpul data yang digunakan dalam penelitian ini adalah teknik komunikasi tidak langsung. Dalam hal ini alat yang digunakan adalah kuisioner (angket) yang dibagikan pada responden. Kemudian diisi langsung oleh responden yang bersangkutan, tiap pilihan yang telah disediakan untuk setiap pernyataan. Kuisioner yang digunakan dalam penelitian ini disusun dengan menggunakan skala tingkat (Likert). Metode skala Likert yaitu metode perskala. Pertanyaan sikap yang menggunakan distribusi respon sebagai dasar penentuan nilai skalanya. Teknik Pengolahan Data menggunakan deskriptif kuantitatif. 
4766 Pelaksanaan Supervisi Akademik dan Kemampuan Manajemen Kelas dalam Pelaksanaan Tugas Guru MIN Kota Padang - Azvi Rahmi

DOI: https://doi.org/10.31004/edukatif.v3i6.1488

\section{HASIL PENELITIAN}

Data penelitian ini terdiri dari tiga variabel yaitu data variabel, variabel Pelaksanaan tugas guru Supervisi akademik, kemampuan manajemen kelas. Data tersebut dideskripsikan sebagai berikut: Angket variabel Pelaksanaan tugas guru terdiri dari 54 butir. Maka skor minimum 54 dan skor maksimum 270. Dari jawaban responden, diperoleh skor terendah 141 dan skor tertinggi 228. Hasil pengolahan data diperoleh skor rata-rata (mean) sebesar 192,7, modus (mode) sebesar 189,0, median sebesar 191,0 dan simpangan baku (standar deviation) sebesar 15,3. harga skor rata-rata, modus dan median tidak jauh berbeda dan tidak melebihi satu simpangan baku, ini berarti bahwa distribusi Pelaksanaan tugas guru cenderung normal. Gambaran distribusi frekuensi skor pelaksaan tugas guru, dapat dilihat padang Tabel 1.

Tabel 1. Pelaksanaan Tugas Guru

\begin{tabular}{lcccc}
\hline \multicolumn{1}{c}{ Indikator } & $\begin{array}{c}\text { Skor } \\
\text { Ideal }\end{array}$ & $\begin{array}{c}\text { Rata- } \\
\text { rata }\end{array}$ & $\begin{array}{c}\text { \% Tingkat } \\
\text { Pencapaian }\end{array}$ & Kategori \\
\hline Pperencanaan pembelajaran & 75 & 54,4 & 72,5 & cukup \\
\hline Pelaksanaan pembelajaran & 70 & 51,0 & 72,97 & cukup \\
\hline pelaksanaan evaluasi & 60 & 42,6 & 71,0 & cukup \\
\hline Pelaksanaan biombingan & 35 & 24,0 & 68,7 & cukup \\
\hline Pelaksanaan tugas tambahan & 30 & 20,6 & 68,6 & cukup \\
\hline Keseluruhan skor profesionalisme guru & 270 & 192,7 & 71,3 & cukup \\
\hline
\end{tabular}

Pada Tabel 1 kelihatan bahwa 41\% dari skor pelaksanaan tugas guru berada pada kelas interval, skor rata-rata 13,6\% skor kinerja guru di bawah kelas interval dan skor rata-rata dan 45,5\% berada di atas kelas interval skor rata-rata. Ini berarti bahwa sebagian besar skor pelaksanaan tugas guru berada di atas kelas interval skor rata-rata. Secara umum tingkat capaian skor pelaksanaan tugas guru dengan skor 71,3\% dari skor ideal berada pada kategori cukup ini menunjukkan bahwa pelaksanaan tugas guru kurang baik, telihat bahwa, semua indikator pelaksanaan tugas guru berada pada kategori cukup dengan rentang pencapain antara 68,6\%72,9\%.

\section{Supervisi akademik}

Angket variabel supervisi akademik oleh pengawas terdiri dari 37 butir. Maka skor minimum 37 dan skor maksimum 185. Dari jawaban responden, diperoleh skor terendah 120 dan skor tertinggi 151. Hasil pengolahan data diperoleh skor rata-rata (mean) sebesar 138,2, modus (mode) sebesar 132,0, median sebesar 139,0 dan simpangan baku (standar deviation) sebesar 7,5. harga skor rata-rata, modus dan median tidak jauh berbeda dan tidak melebih satu simpangan baku, ini berarti bahwa distribusi sepervisi akademik oleh pengawas cenderung normal. Gambaran distribusi frekuensi skor supervisi akademik oleh pengawas, dapat dilihat padang Tabel 2

Tabel 2. Tingkat Pencapaian Respon setiap Indikator Supervisi Akademik

\begin{tabular}{lcccc}
\hline \multicolumn{1}{c}{ Indikator } & $\begin{array}{c}\text { Skor } \\
\text { Ideal }\end{array}$ & $\begin{array}{c}\text { Rata- } \\
\text { rata }\end{array}$ & $\begin{array}{c}\text { \% Tingkat } \\
\text { Pencapaian }\end{array}$ & Kategori \\
\hline Pelaksanaan monitoring & 35 & 26,6 & 76,1 & cukup \\
\hline Melaksanakan eveluasi & 40 & 30,0 & 75,1 & cukup \\
\hline Melaksanakan bimbingan & 110 & 81,5 & 74,1 & cukup \\
\hline Keseluruhan Skor & 185 & 138,2 & 74,7 & cukup \\
\hline
\end{tabular}

Hasil analisis tingkat capaian responden setiap indikator supervisi akademik oleh pengawas dapat bahwa supervisi akademik masih termasuk kedalam kategori cukup hal ini terlihat dari pelaksanaan monitoring, melaksanakan evaluasi dan melaksanakan pembimbingan. 
4767 Pelaksanaan Supervisi Akademik dan Kemampuan Manajemen Kelas dalam Pelaksanaan Tugas Guru MIN Kota Padang - Azvi Rahmi

DOI: https://doi.org/10.31004/edukatif.v3i6.1488

\section{Kemampuan Manajemen Kelas}

Angket variabel kemampuan manajemen kelas terdiri dari 47 butir. Maka skor minimum 47 dan skor maksimum 235. Dari jawaban responden, diperoleh skor terendah 151 dan skor tertinggi 201. Hasil pengolahan data diperoleh skor rata-rata (mean) sebesar 178,2, modus (mode) sebesar 184,0 median sebesar 179,5 dan simpangan baku (standar deviation) sebesar 10,5. harga skor rata-rata, modus dan median tidak jauh berbeda dan tidak melebih satu simpangan baku, ini berarti bahwa distribusi kemampuan manajemen kelas cenderung normal. Selanjutnya hasil analisis tingkat capaian responden setiap indikator kemampuan manajemen kelas disajikan pada Tabel 3.

Tabel 3. Tingkat Pencapaian Respon setiap Indikator Kemampuan Manajemen Kelas

\begin{tabular}{lcccc}
\hline \multicolumn{1}{c}{ Indikator } & $\begin{array}{c}\text { Skor } \\
\text { Ideal }\end{array}$ & $\begin{array}{c}\text { Rata- } \\
\text { rata }\end{array}$ & $\begin{array}{c}\text { \% Tingkat } \\
\text { Pencapaian }\end{array}$ & Kategori \\
\hline Melaksanakan tata tertip & 40 & 30,4 & 75,9 & Cukup \\
\hline Mengatur ruang belajar & 55 & 41,1 & 74,7 & Cukup \\
\hline Menyiapkan Sarana & 45 & 34,5 & 76,8 & Cukup \\
\hline Menyiapkan bahan ajar & 40 & 30,0 & 75,8 & Cukup \\
\hline Situasi kelas yang nyaman & 30 & 22,7 & 75,9 & Cukup \\
\hline Mendisiplin peserta didik & 25 & 19,0 & 76,2 & Cukup \\
\hline Keseluruhan Skor Ideal & 235 & 178,2 & 75,8 & Cukup \\
\hline
\end{tabular}

Data di atas mengambarkan bahwa kemampuan manajerial kepala MIN Kota Padang masih termasuk kategori cukup hal ini dilihat dari aspek melaksanakan tata tertib, mengatur ruang belajar, menyiapkan sarana, menyiapkan bahan ajar, mengelola situasi kelas yang nyaman dan mendisplikan peserta didik.

\section{PEMBAHASAN}

Pelaskanaan supervisi akademik terhadap pelaksanaan tugas guru temuan penelitian menunjukkan bahwa supervisi akademik yang diukur oleh pelaksanaan tugas guru memiliki kontribusi yang positif dan signifikan terhadap tinggi rendahnya pelaksanaan tugas guru. Besaranya kontribusi supervisi akademik yang secara langsung berkontribusi $13,54 \%$. Oleh karena itu, untuk mengoptimalkan pelaksanaan tugas guru harus diupayakan meningkatkan supervisi akademik yang dilakukan sehingga pelaksanaan tugas guru dapat berjalan dengan baik. Hasil penelitian ini sama dengan teori (Suhardan, 2012) supervisi hadir untuk membimbing pertumbuhan dan kemampuan dan kecakapan profesional guru dalam melaksanakan tugas, bila guru memperoleh pembinaan dan kemudian menyadari pentingnya meningkatkan kemampuan diri, guru tumbuh dan makin bertambah mampu dalam melaksanakan tugasnya. Hasil penelitian ini sejalan dengan penelitian (Baharuddin, 2010) dalam penelitiannya menyatakan bahwa supervisi akademik berkontribusi sebesar 31,5\% terhadap pelaksanaan tugas guru SMP N di Kecamatan Simpang Alahan Mati. Kemudian (Chan et al., 2019) menyatakan bahwa supervisi berkontribusi terhadap pelaksanaan tugas guru sebesar $12,2 \%$. Penelitian ini menunjukkan bahwa supervisi akademik berkontribusi signifikan terhadap pelaksanaan tugas guru. Supervisi yang baik harus mampu membuat guru semakin baik dalam pelaksanaan tugas yaitu guru semakin menguasai kompetensi, baik kompetensi kepribadian, kompetensi sosial, kompetensi pedagogik, kompetensi profesional, dengan adanya pelaksanaan supervisi yang dilakukan oleh pengawas diharapkan memberikan dampak terhadap pelaksanaan tugas guru. Perilaku supervisi akademik secara langsung berhubungan dan berpengaruh terhadap perilaku guru dalam melaksanakan tugas di sekolah sehingga perilakunya semakin baik itu akan mempengaruhi perilaku belajar peserta didik (Stit \& Nusantara, 2019).

Kehadiran supervisi akademik digunakan untuk memajukan pembelajaran melalui pertumbuhan kemampuan guru-gurunya, supervisi akdemik mendorong guru menjadi lebih berdaya, dan situasi mengajar 
4768 Pelaksanaan Supervisi Akademik dan Kemampuan Manajemen Kelas dalam Pelaksanaan Tugas Guru MIN Kota Padang - Azvi Rahmi

DOI: https://doi.org/10.31004/edukatif.v3i6.1488

belajar menjadi lebih baik pengajaran lebih efektif, guru menjadi lebih puas dalam melaksanakan pekerjaannya. Dengan demikian sistem pendidikan dapat berfungsi sebagaimana semenstinya. Supervisi akademik yang menitik beratkan pengamatan supervisor pada masalah-masalah akademik, yaitu hal-hal yang langsung berada dalam lingkungan kegiatan pembelajaran pada waktu siswa sedalam proses mempelajari sesuatu, supervisi akademik bertujuan untuk memberdayakan guru dalam melaksanakan tanggung jawabnya sebagai tenaga profesional yang dimanifestasikan melalui kinerja membelajarkan peserta didik (Putri \& Imaniyati, 2017), (Isbianti \& Andriani, 2021) (Susanti, 2019).

Kemampuan manajemen kelas terhadap pelaksanaan tugas guru temuan penelitian ini menunjukkan bahwa kemampuan manajemen kelas berkontribusi secara langsung terhadap pelaksanaan tugas guru sebesar 13,54\% . Hal ini berarti bahwa pelaksanaan tugas guru dapat diinterprestasikan melalui kemampuan manajemen kelas. Sejalan dengan toeri yang dikemukakan oleh (Sardiman, 2016)" Pengelolaan kelas merupakan upaya dalam mendayagunakan potensi kelas". Kelas mempunyai peranan dan fungsi tertentu dalam menunjang keberhasilan proses interaksi edukatif, agar memberikan dorongan dan rangsangan terhadap anak didik untuk belajar, kelas harus dikelola sebaik-baiknya oleh guru. Sehingga pelaksanaan tugas guru dapat berjalan secara efektif Hasil penelitian ini deperkuat oleh teori (Suhardan, 2012). Manajemen kelas adalah proses pemberdayaan guru dalam melaksanakan tugas dalam pembelajaran baik material elemen mauoun human elemen di dalam kelas oleh guru sehingga memberikan dukungan terhadap kegiatan belajar siswa dan tugas guru. Hasil penelitian ini sejalan dengan (Erpidawati \& Susanti, 2019) menyatakan bahwa kemampuan manajemen kelas dan supervisi secara bersama-sama berkontribusi terhadap pelaksanaan tugas guru sebesar $62,51 \%$. Hasil penelitian ini menunjukkan hasil yang sangat signifikan bahwa kemampuan manajemen kelas dan pelaksanaan supervisi akan membantu meningkatkan pelaksanaan tugas guru secara signifikan dan sebaliknya. Secara deskriptif kemampuan manajemen kelas guru MIN Kota Padang terlihat bahwa kemampuan manajemen kelas guru masih tergolong kategori cukup, dalam hal ini terlihat ketika guru melaksanakan tata tertip, mengatur ruang belajar, menyiapkan sarana dan prasarana, menyiapkan bahan ajar, situasi kelas yang nyaman, serta mendisiplinkan peserta didik. Keberhasilan guru mengajar di kelas tidak cukup bila hanya berbekal pada pengetahuan tentang kurikulum, metode mengajar, media pengajaran, dan wawasan tentang materi yang akan disampaikan kepada anak didik. Di samping itu guru harus menguasai kiat manajemen kelas. Guru hendaknya dapat menciptakan dan mempertahankan kondisi kelas yang menguntungkan bagi anak didik supaya tumbuh iklim pembelajaran yang aktif, kreatif, efektif, dan menyenangkan. Manajemen kelas yang baik sangat penting untuk mendorong tercapainya hasil pendidikan yang positif (Arfani \& Sugiyono, 2014). (Artantri, 2011).(Hasan Hasan, 2019).

Pelaskanaan supervisi akademik melalui kemampuan manajemen kelas berkontribusi terhadap pelaksanaan tugas guru Hasil temuan ini mengambarkan bahwa supervisi akademik melalui manajemen kelas berkontribusi terhadap pelaksanaan tugas guru sebesar 25,2\%, hasil penelitian ini dapat diartikan bahwa pelaksanaan tugas guru dalam diinterprestasikan supervisi akademik dapat diinterprestasikan melalui kemampuan manajemen kelas (Sintawati, 2020). Supervisi akademik bertujuan untuk suatu kegiatan membimbing guru dalam melaskanakan manajemen kelas, yaitu segala usaha yang diarahkan untuk mewujudkan suasana belajar mengajar yang efisien dan menyenangkan serta dapat memotivasi siswa belajar dengan baik sesuai dengan kemampuan, melalaui supervisi akademik bertujuan untuk membina guru dalam mengelola pembelajaran dan mengelola peserta didik. Proses pendidikan tidak akan terjadi dengan sendirinya melainkan harus direncanakan, diprogram, dan difasilitasi dengan dukungan dan partisipasi aktif guru sebagai pendidik. Tugas dan tanggung jawab guru adalah mengubah perilaku peserta didik ke arah pencapaian tujuan pendidikan. Oleh karena itu, pencapaian tujuan pendidikan sangat bergantung kepada pelaksanaan tugas dan kinerja guru di samping kemampuan peserta didik itu sendiri serta dukungan komponen sistem pendidikan lainnya. Posisi strategis guru merupakan salah satu faktor penentu kualitas proses dan hasil pendidikan. Faktor yang mempengaruhi pengelolaan dan pengembangan dunia pendidikan yang harus diperhitungkan, antara lain 
4769 Pelaksanaan Supervisi Akademik dan Kemampuan Manajemen Kelas dalam Pelaksanaan Tugas Guru MIN Kota Padang - Azvi Rahmi

DOI: https://doi.org/10.31004/edukatif.v3i6.1488

(1) laju perubahan cepat dan penuh tantangan, (2) tuntutan masyarakat yang lebih maju, (3) kehidupan yang sangat dipengaruhi oleh perkembangan ilmu pengetahuan, teknologi dan seni, (4) arus globalisasi dalam berbagai bentuk (Kristanti, 2017), (Hafiedh Hasan, 2017), (Kurniati, 2019) (Susanti, 2019).

\section{SIMPULAN}

Supervisi akademik memberikan dampak terhadap pelaksanaan tugas guru secara deskriptif bahwa supervisi akademik termasuk kategori cukup. Kemampuan manajemen kelas secara langsung berdampak terhadap pelakasnaan tugas guru secara deskriptif bahwa kemampuan manajemen kelas termasuk kategori cukup dan supervisi akademik melalui kemampuan manajemen kelas berkontribusi dalam pelaksanaan tugas guru dengan kategori cukup.

\section{DAFTAR PUSTAKA}

Arfani, J. W., \& Sugiyono, S. (2014). Manajemen Kelas Yang Efektif: Penelitian Di Tiga Sekolah Menengah Atas. Jurnal Akuntabilitas Manajemen Pendidikan, 2(1), 44-57. Https://Doi.Org/10.21831/Amp.V2i1.2408

Artantri. (2011). Manajemen Kelas Dalam Pembelajaran Matematika Untuk Siswa Inklusi Di Sd Tumbuh (P. 2011). Uny.

Baharuddin. (2010). Baharuddin Dan Esa Nur Wahyuni, Teori Belajar Dan. Ar-Ruzz Media.

Chan, F., Kurniawan, A. R., . N., Herawati, N., Efendi, R. N., \& Mulyani, J. S. (2019). Strategi Guru Dalam Mengelola Kelas Di Sekolah Dasar. International Journal Of Elementary Education, 3(4), 439. Https://Doi.Org/10.23887//jee.V3i4.21749

Erpidawati, E., \& Susanti, E. (2019). Kontribusi Pengelolaan Manajemen Kelas Terhadap Hasil Belajar Mahasiswa Fakultas Kesehatan Dan Mipa Universitas Muhammadiyah Sumatera Barat. Jurnal Benefita, 1(1), 70. Https://Doi.Org/10.22216/Jbe.V1i1.2405

Hasan, Hafiedh. (2017). Internalisasi Religius Dalam Kompetensi Guru Agama Islam. Jurnal Madaniyah, 7(2), 284-298.

Hasan, Hasan. (2019). Pelaksanaan Supervisi Kelas Kepala Sekolah Terhadap Guru Pai Di Sekolah Dasar Negeri Kecamatan Bukitraya. Al-Mutharahah: Jurnal Penelitian Dan Kajian Sosial Keagamaan, 16(2), 317-346.

Isbianti, P., \& Andriani, D. E. (2021). Jurnal Manajemen Pendidikan Pelaksanaan Supervisi Akademik Oleh Kepala Sekolah Menengah Pertama Negeri Di Klaten Jawa Tengah Academic Supervision Practices Of Junior High School Principals In Klaten, Central Java. 3(1), 75-85.

Jumali. (2014). Profesionalisme Guru-Guru Madrasah Ibtidaiyah Muhammadiyah Ceper; Suatu Tinjauan Dari Aspek Tingkat Pendidikan. Jurnal Pendidikan Ilmu Sosial, 24(2), 45-52. Journals.Ums.Ac.Id/Index.Php/Jpis/Article/Download/679/413

Kristanti, D. (2017). Faktor-Faktor Yang Mempengaruhi Pelaksanaan Tugas Pokok Guru (Studi Pada Ma Al Muttaquun Wates). Ekonika: Jurnal Ekonomi Universitas Kadiri, 1(1), 13-25. Https://Doi.Org/10.30737/Ekonika.V1i1.2

Kurniati, M. (2019). Pengelolaan Supervisi Akademik Di Sekolah Dasar Negeri Pulau Rimau. Manajemen, $4(2)$.

Misro. (2021). Upaya Meningkatkan Kemampuan Guru Dalam Pengelolaan Pbm ( Proses Belajar Mengajar) Melalui Supervisi Akademik Dengan Pendekatan Kolaboratif Di Smpn 3 Tungkal Jaya Tahun Pelajaran 2019 / 2020. Lipnas. 
4770 Pelaksanaan Supervisi Akademik dan Kemampuan Manajemen Kelas dalam Pelaksanaan Tugas Guru MIN Kota Padang - Azvi Rahmi

DOI: https://doi.org/10.31004/edukatif.v3i6.1488

Ninlawan, G. (2015). Factors Which Affect Teachers' Professional Development In Teaching Innovation And Educational Technology In The 21st Century Under The Bureau Of Special Education, Office Of The Basic Education Commission. Procedia - Social And Behavioral Sciences, 197(February), 1732-1735. Https://Doi.Org/10.1016/J.Sbspro.2015.07.228

Perpres. (2005). Undang-Undang Republik Indonesia Tentang Guru Dan Dosen. In Journal Of Materials Processing Technology (Vol. 1, Issue 1).

Http://Dx.Doi.Org/10.1016/J.Cirp.2016.06.001\%0ahttp://Dx.Doi.Org/10.1016/J.Powtec.2016.12.055\%0ahttps ://Doi.Org/10.1016/J.Ijfatigue.2019.02.006\%0ahttps://Doi.Org/10.1016/J.Matlet.2019.04.024\%0ahttps:// Doi.Org/10.1016/J.Matlet.2019.127252\%0ahttp://Dx.Doi.O

Putri, A. D. K., \& Imaniyati, N. (2017). Pengembangan Profesi Guru Dalam Meningkatkan Kinerja Guru. Jurnal Pendidikan Manajemen Perkantoran, 2(2), 93. Https://Doi.Org/10.17509/Jpm.V2i2.8109

Sardiman. (2016). Interaksi Dan Motivasi Belajar Mengajar (Vol. 1, Issue 2). Raja Grafindo Persada.

Sintawati, S. (2020). Meningkatkan Kemampuan Guru | Sri Sintawati. Al-Muaddib, Ii(April), 28-41.

Stit, S. H., \& Nusantara, P. (2019). Supervisi Akademik Kunjungan Kelas Oleh Kepala Sekolah Dalam Rangka Meningkatkan Kinerja Guru (Studi Kasus Di Smp Nw Jerua). Jurnal Pendidikan Dasar, 3(2), 114-135. Https://Ejournal.Stitpn.Ac.Id/Index.Php/Fondatia

Suhardan, D. (2012). Manajemen Pendidikan. Alfabeta.

Susanti, N. (2019). Manajemen Supervisi Akademik Dalam Lembaga Pendidikan Islam. Al-Kahfi, Iv(2), 1-13. 